\title{
Influence of installation of displacement ventilation diffusers above occupied zone on the vertical temperature gradient in simulated office rooms
}

\author{
Panu Mustakallio, ${ }^{1, *}$ Risto Kosonen ${ }^{2,4}$, Mika Ruponen $^{3}$, and Natalia Lastovets $^{2}$ \\ ${ }^{1}$ Halton Oy, Haltonintie 1-3, 47400 Kausala, Finland \\ ${ }^{2}$ Aalto University, Department of mechanical engineering, Sähkömiehentie 4, 00076 Espoo, Finland \\ ${ }^{3}$ South-Eastern Finland University of Applied Sciences, Patteristonkatu 3 D, 50100 Mikkeli, Finland \\ ${ }^{4}$ College of Urban Construction, Nanjing Tech University, China
}

\begin{abstract}
Displacement ventilation diffusers are typically installed to the occupied zone, which can limit the utilization of the displacement ventilation. This paper presents the full-scale test results of two simulated office rooms with installation of displacement diffusers near wall, above the occupied zone. Vertical temperature gradients are compared to full-scale tests with installation of displacement diffusers to the occupied zone. The full-scale test setup consisted of two displacement diffusers and ceiling exhaust in wellinsulated room with $20.7 \mathrm{~m}^{2}$ floor area and room heights of $5.1 \mathrm{~m}$ and $3.3 \mathrm{~m}$. The internal heat loads simulated situations with 10 occupants (simulated with heated cylinders), fluorescent lighting units, solar load on window surface (heated foils in one wall) without/with direct solar load on floor (heated foil on floor). The installation of displacement ventilation diffusers above occupied zone influenced on the vertical temperature gradient above the occupied zone only slightly. It reduced the vertical temperature gradient in the occupied zone. This confirms the operation of the displacement ventilation with this installation. This can be advantageous due to the smaller temperature stratification in the occupied zone, still the ventilation efficiency can be slightly lower comparing to the typical installation of the displacement diffusers.
\end{abstract}

\section{Introduction}

Displacement ventilation is typically used in high spaces by installing supply air diffusers directly to the occupied zone and exhaust air terminals to the ceiling level. Advantage of displacement ventilation is the ability to maintain are uniform indoor climate conditions in the occupied zone with varying room heat load levels [1]. This is based on cool supply air distribution smoothly along the convection flows. Opposite to the ceiling installed mixing ventilation where supply air distribution collides with convection flows. With displacement ventilation recirculation of heat loads from upper level of room back to the occupied zone can be also prevented. This generates vertical temperature gradient in the room and can give energy efficiency benefit due to lower required cooling capacity to maintain occupied zone in cooling design temperature. Other benefit can be cleaner room air in the occupied zone due to ventilation air supply straight to occupied zone [2].

Space required for installation of supply air diffusers and the area near the diffuser with higher draught risk in the occupied zone can limit the utilization of the displacement ventilation. This may be avoided if diffusers are installed above the occupied zone by supplying air along the wall downward onto floor level.
This paper presents the full-scale test results of two simulated office rooms with installation of displacement diffusers near wall, above the occupied zone. Vertical temperature gradients are compared to full-scale tests with installation of displacement diffusers to the occupied zone. The same test setup with installation of displacement diffusers to the occupied zone was used for validation of calculation models [3, 4] and CFDsimulation in displacement ventilation cases [5].

\section{Methods}

The full-scale test setup consisted of displacement diffusers with perforated front face and ceiling exhaust in well-insulated test room with $20.7 \mathrm{~m} 2$ floor area (4.6 $\mathrm{m} \times 4.6 \mathrm{~m}$ ). Movable ceiling of the test room was used to simulate office rooms with room heights $5.1 \mathrm{~m}$ and 3.3 m. Displacement diffusers were installed to two locations: 1) On the floor and near one wall supplying air horizontally along floor to the occupied zone, and 2) front face at $2.7 \mathrm{~m}$ height from floor and near same wall as in the installation 1 supplying air vertically downwards along wall. Full-scale test setup is shown in Figure 1 and 2 in displacement diffuser installation 1 . Installation 2 is shown in Figure 3.

* Corresponding author: panu.mustakallio@halton.com 


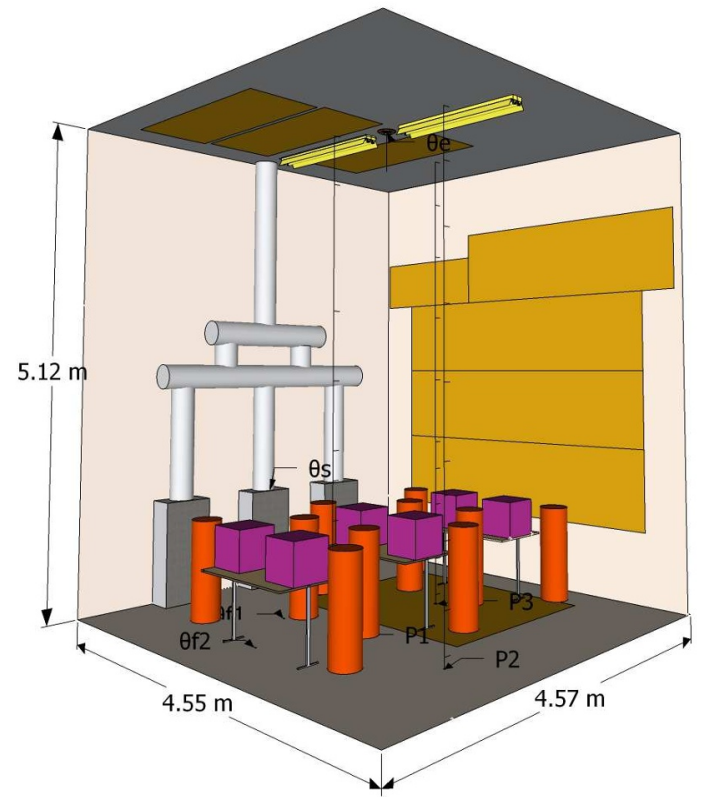

person simulators

computer simulators

heated foils on the wall, floor and ceiling

fluorescent lighting units

Measurement points:

P1, P2, P3 - room air temperatures;

$\theta$ fl, $\theta$ f 2 - floor surface temperatures;

$\theta \mathrm{s}$ - supply air temperature;

$\theta \mathrm{e}-$ exhaust air temperature

Fig. 1. Simulated office room with ceiling height $5.1 \mathrm{~m}$.

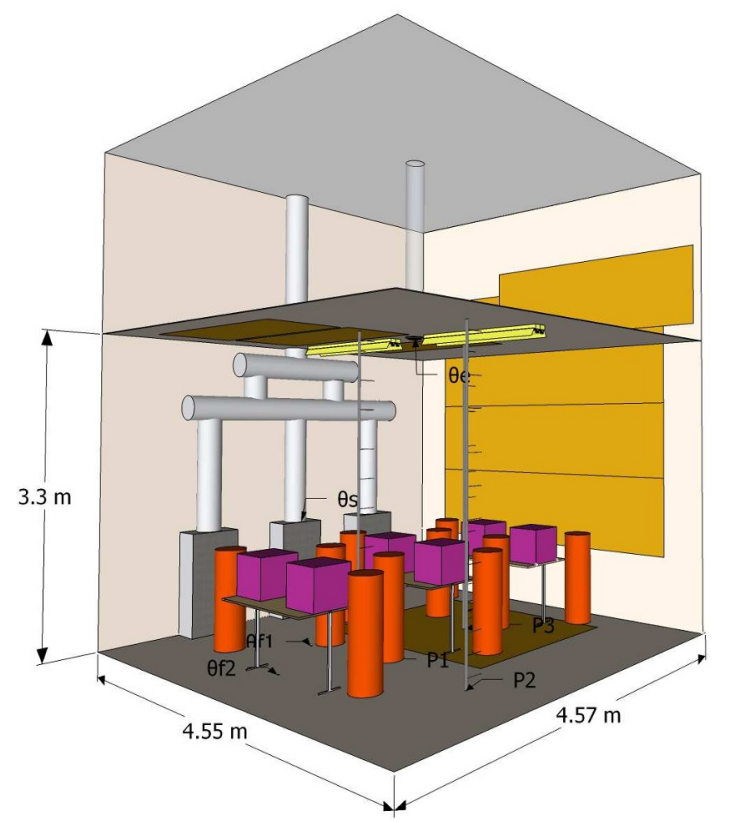

Fig. 2. Simulated office room with ceiling height $3.3 \mathrm{~m}$ with same heat loads (except only two lower heated foils on the wall used to simulate window).

The internal heat loads consisted of 10 heated cylinders representing persons, heated foils in one wall representing solar load on window surface, persons, heated foil on floor representing direct solar load and fluorescent lighting units. Heat load level was 72 / 85
$\mathrm{W} / \mathrm{m}^{2}$ floor in the case without / with direct solar load. Full-scale tests were done in steady state conditions. Heat loads in studied cases are shown in Table 1. Supply airflow rate were $100 \mathrm{l} / \mathrm{s}$ and $180 \mathrm{l} / \mathrm{s}$ in the case with direct solar load, and $100 \mathrm{l} / \mathrm{s}$ without solar load.
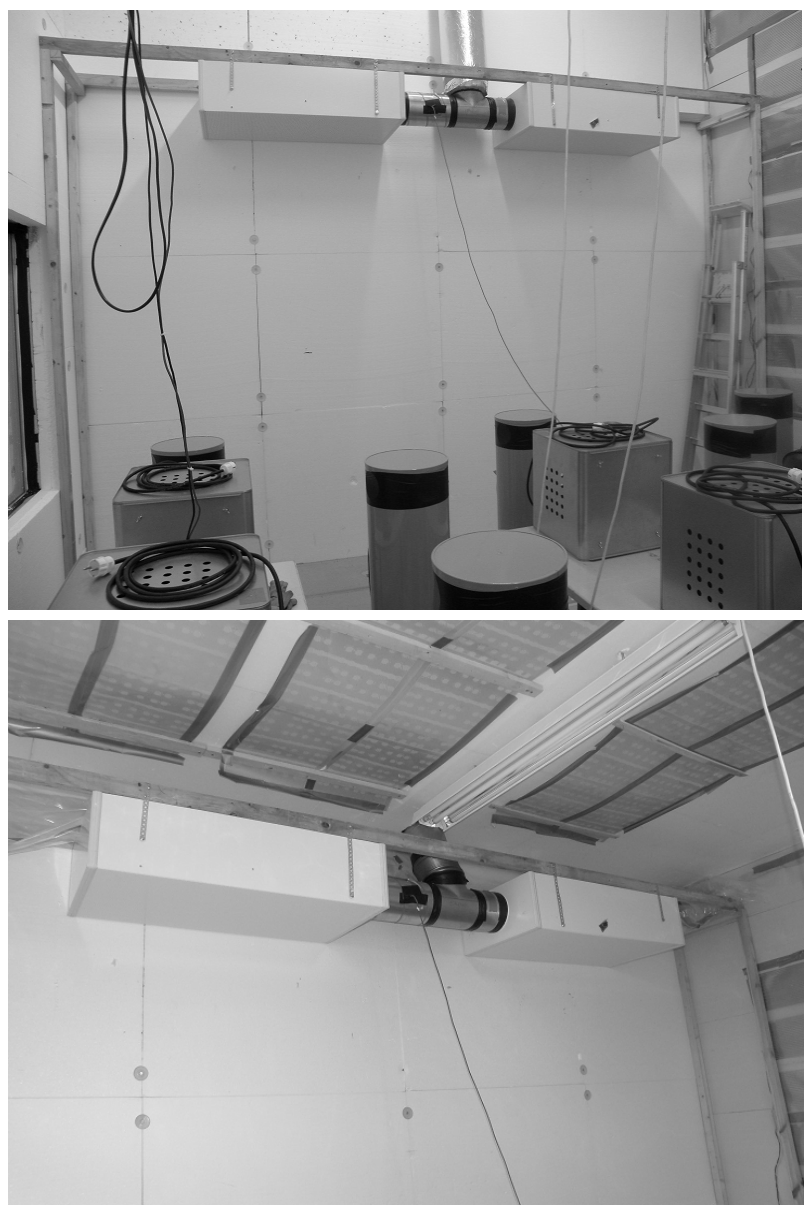

Fig. 3. Installation of displacement diffusers near ceiling in cases with $5.1 \mathrm{~m}$ (top) and $3.3 \mathrm{~m}$ ceiling height (bottom).

Table 1. Heat loads and ventilation parameters.

\begin{tabular}{|c|c|c|c|c|}
\hline & $\begin{array}{c}\text { Case5.1 } \\
\text { DS0 } \\
\text { F/W100 }\end{array}$ & $\begin{array}{c}\text { Case3.3 } \\
\text { DS0 } \\
\text { F/W100 }\end{array}$ & $\begin{array}{c}\text { Case5.1 } \\
\text { DS260 } \\
- \text { F/W } \\
1 \overline{100} / 180\end{array}$ & $\begin{array}{c}\text { Case3.3 } \\
\text { DS260 } \\
- \text { F/W } \\
1 \overline{100} / 180\end{array}$ \\
\hline Occupants & $750 \mathrm{~W}$ & $750 \mathrm{~W}$ & $750 \mathrm{~W}$ & $750 \mathrm{~W}$ \\
\hline Computers & $0 \mathrm{~W}$ & $0 \mathrm{~W}$ & $0 \mathrm{~W}$ & $0 \mathrm{~W}$ \\
\hline Window foils & $520 \mathrm{~W}$ & $520 \mathrm{~W}$ & $520 \mathrm{~W}$ & $520 \mathrm{~W}$ \\
\hline Floor foil & $0 \mathrm{~W}$ & $0 \mathrm{~W}$ & $260 \mathrm{~W}$ & $260 \mathrm{~W}$ \\
\hline Ceiling foil & $0 \mathrm{~W}$ & $0 \mathrm{~W}$ & $0 \mathrm{~W}$ & $0 \mathrm{~W}$ \\
\hline Lighting & $232 \mathrm{~W}$ & $232 \mathrm{~W}$ & $232 \mathrm{~W}$ & $232 \mathrm{~W}$ \\
\hline $\begin{array}{c}\text { Supply } \\
\text { airflow } \\
\end{array}$ & $100 \mathrm{l} / \mathrm{s}$ & $100 \mathrm{l} / \mathrm{s}$ & $\begin{array}{c}100 / \\
\mathbf{1 8 0} \mathrm{l} / \mathrm{s} \\
\end{array}$ & $\begin{array}{c}100 / \\
\mathbf{1 8 0} 1 / \mathrm{s} \\
\end{array}$ \\
\hline $\begin{array}{l}\text { Supply temp. } \\
\text { floor/wall } \\
\text { installation } \\
\text { (180 1/s bold })\end{array}$ & $\begin{array}{l}16.6 / \\
17.7^{\circ} \mathrm{C}\end{array}$ & $\begin{array}{l}17.8 / \\
18.9^{\circ} \mathrm{C}\end{array}$ & $\begin{array}{l}15.9 / \\
17.8^{\circ} \mathrm{C} \\
\mathbf{1 7 . 2} / \\
\mathbf{1 8 . 1}{ }^{\circ} \mathrm{C}\end{array}$ & $\begin{array}{l}18.1 / \\
18.2^{\circ} \mathrm{C} \\
\mathbf{1 8 . 2} / \\
\mathbf{1 7 . 6}{ }^{\circ} \mathrm{C}\end{array}$ \\
\hline $\begin{array}{c}\text { Exhaust } \\
\text { temp. } \\
\text { floor/wall } \\
\text { installation }\end{array}$ & $\begin{array}{l}26.1 / \\
26.7^{\circ} \mathrm{C}\end{array}$ & $\begin{array}{l}26.6 / \\
27.7^{\circ} \mathrm{C}\end{array}$ & $\begin{array}{l}27.3 / \\
28.2^{\circ} \mathrm{C} \\
\mathbf{2 3 . 9} / \\
\mathbf{2 5 . 0}{ }^{\circ} \mathrm{C}\end{array}$ & $\begin{array}{l}28.8 / \\
28.4^{\circ} \mathrm{C} \\
\mathbf{2 4 . 0} / \\
\mathbf{2 3 . 8}{ }^{\circ} \mathrm{C}\end{array}$ \\
\hline
\end{tabular}


Two displacement ventilation diffusers were used in the measurements. Vertical temperature profiles were measured from three locations (P1-P3 in Fig. 1) at eight heights with calibrated PT100 sensors (accuracy $+/-0.2$ ${ }^{\circ} \mathrm{C}$ ). Black ball temperature was measured from $1.1 \mathrm{~m}$ height from each location. Inner wall surface, ambient, supply air and exhaust air temperatures were measured. Supply and exhaust air flow rate measurements were calibrated with orifice plate measurement, and air flow rates balanced during the measurements.

The ductwork in the test room was insulated and all surfaces of the test room were covered with $0.1 \mathrm{~m}$ polystyrene plates and plastic foil for minimizing the effect of ambient conditions for the vertical temperature stratification. Still some heat flux through the wall was affecting to the measurements especially in the case of higher room. This can be measured when measuring the total amount of electrical power for the internal heat loads, measuring supply air flow and temperature and comparing the calculated exhaust air temperature and measured exhaust air temperature.

\section{Results}

The measured vertical temperature gradient in three locations P1-P3 differed only slightly. Maximum standard deviation was at $0.1 \mathrm{~m}$ height from floor $0.8^{\circ} \mathrm{C}$ and at higher heights $0.4{ }^{\circ} \mathrm{C}$. For that reason, vertical temperature gradients in the following are based on average temperature readings (P1-P3) at each measured height. Temperature gradients in studied cases are presented in Figures 4-9. There are also shown vertical temperature gradients with $2.7 \mathrm{~m}$ wall installation where they are shifted accordingly to the supply air temperature difference to the corresponding case with diffuser installation on floor.

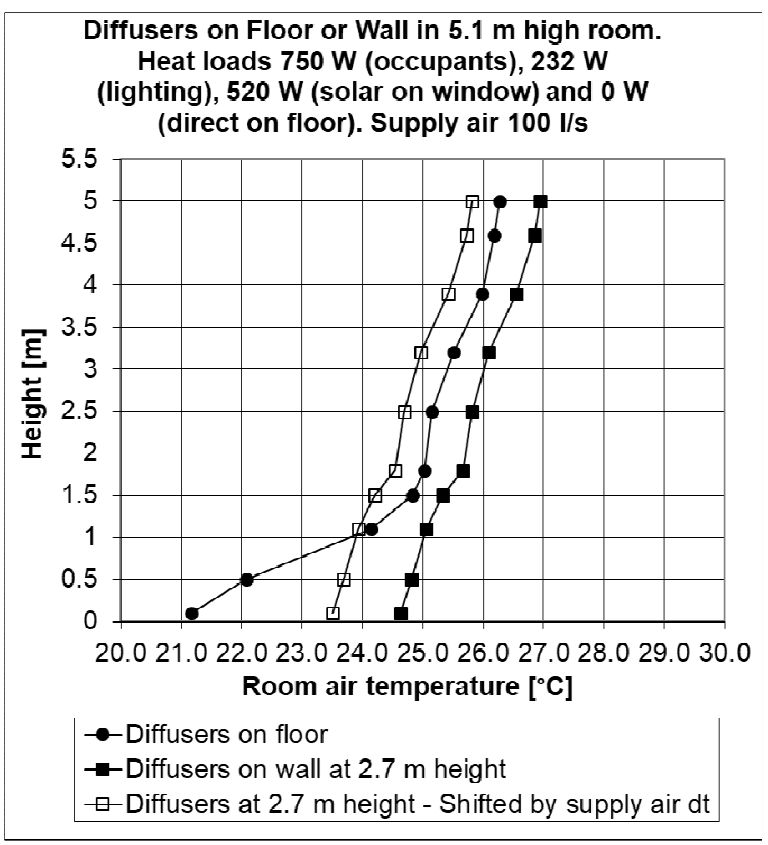

Fig. 4. Vertical temperature gradient with room height $5.1 \mathrm{~m}$, heat load level $72 \mathrm{~W} / \mathrm{m}^{2}$ floor and supply airflow $100 \mathrm{l} / \mathrm{s}$. Same legend applies also to Figures 5-9.

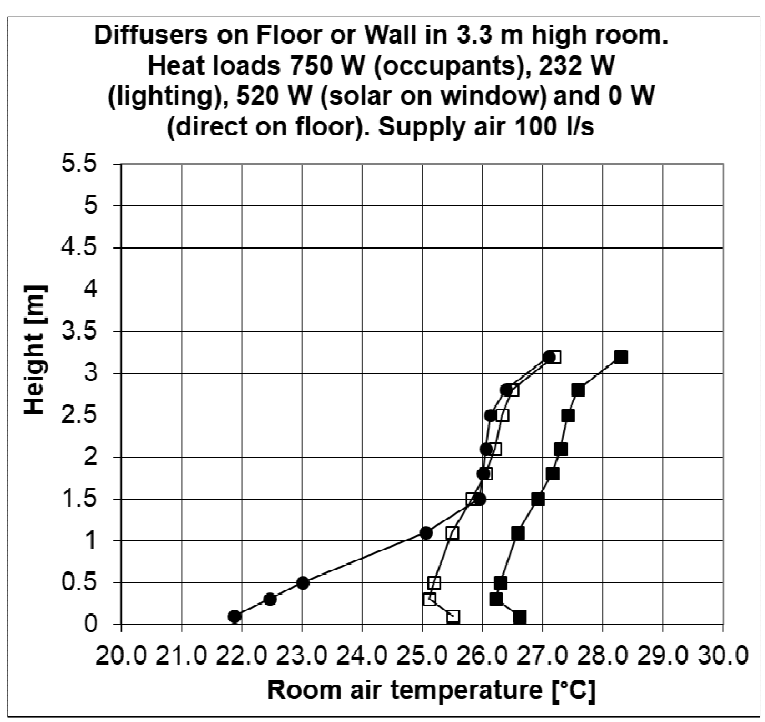

Fig. 5. Vertical temperature gradient with room height $3.3 \mathrm{~m}$, heat load level $72 \mathrm{~W} / \mathrm{m}^{2}$ floor and supply airflow $100 \mathrm{l} / \mathrm{s}$.

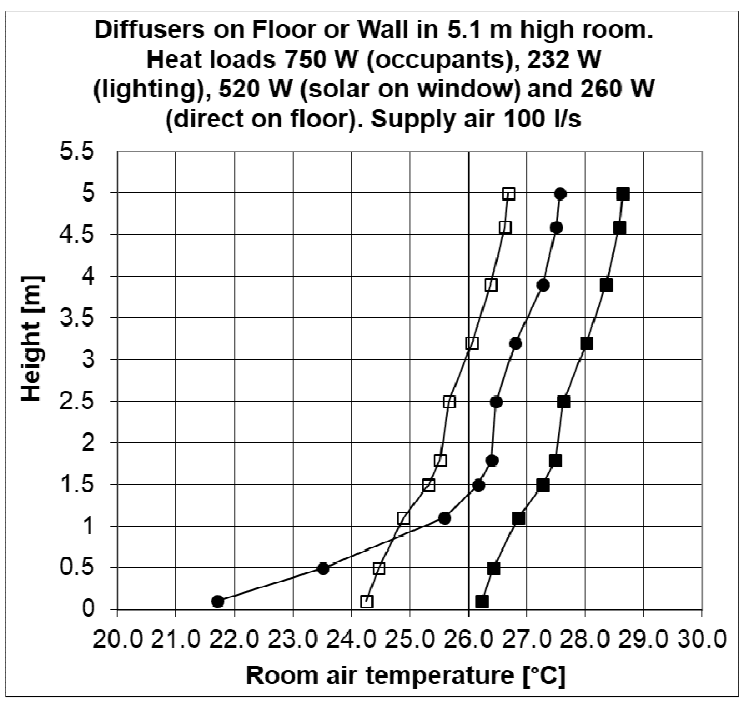

Fig. 6. Vertical temperature gradient with room height $5.1 \mathrm{~m}$, heat load level $85 \mathrm{~W} / \mathrm{m}^{2}$ floor and supply airflow $100 \mathrm{l} / \mathrm{s}$.

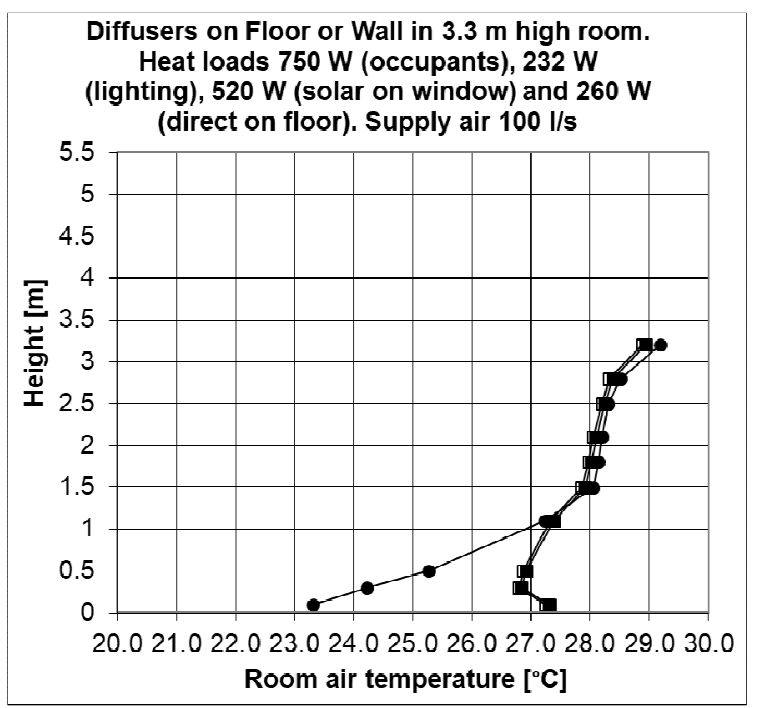

Fig. 7. Vertical temperature gradient with room height $3.3 \mathrm{~m}$, heat load level $85 \mathrm{~W} / \mathrm{m}^{2}$ floor and supply airflow $100 \mathrm{l} / \mathrm{s}$. 


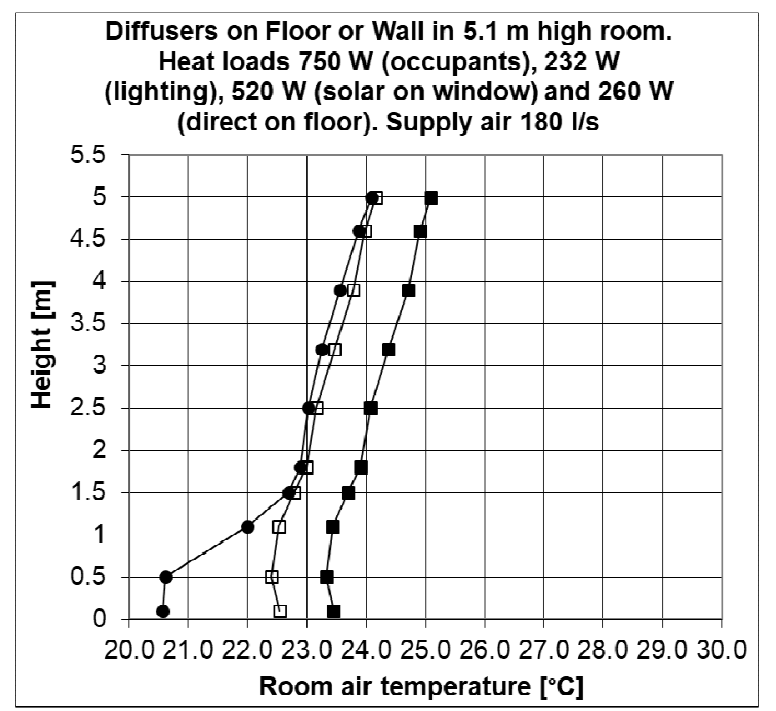

Fig. 8. Vertical temperature gradient with room height $5.1 \mathrm{~m}$, heat load level $85 \mathrm{~W} / \mathrm{m}^{2}$ floor and supply airflow $180 \mathrm{l} / \mathrm{s}$.

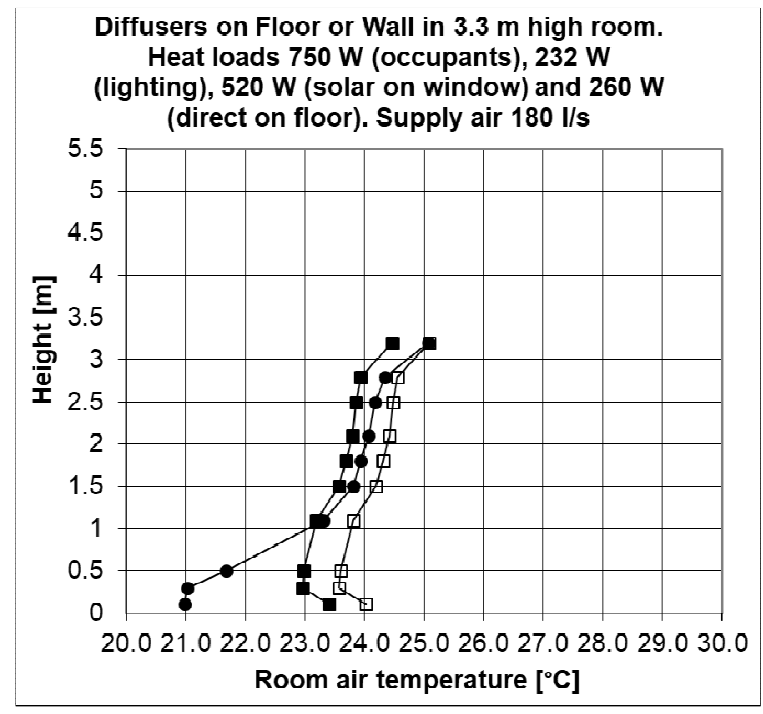

Fig. 9. Vertical temperature gradient with room height $3.3 \mathrm{~m}$, heat load level $85 \mathrm{~W} / \mathrm{m}^{2}$ floor and supply airflow $180 \mathrm{l} / \mathrm{s}$.

Vertical temperature gradients between $0.1 \mathrm{~m}$ and 1.1 $\mathrm{m}$ height in the cases without direct solar load were $(3.0 /$ $\left.1.1{ }^{\circ} \mathrm{C}\right) /\left(0.4 /-0.3{ }^{\circ} \mathrm{C}\right)$ and between $0.1 \mathrm{~m}$ and $1.8 \mathrm{~m}$ $\left(3.9 / 4.1^{\circ} \mathrm{C}\right) /\left(1.0 / 0.5^{\circ} \mathrm{C}\right)$ [diffuser floor installation $(5.1 \mathrm{~m} / 3.3 \mathrm{~m}$ room $) /$ wall installation at $2.7 \mathrm{~m}(5.1 \mathrm{~m} /$ $3.3 \mathrm{~m}$ room)]. In the cases with direct solar load and supply airflow $100 \mathrm{l} / \mathrm{s}$, vertical temperature gradients were $\left(3.9 / 4.7^{\circ} \mathrm{C}\right) /\left(0.6 /-0.4^{\circ} \mathrm{C}\right)$ and $\left(4.7 / 4.8^{\circ} \mathrm{C}\right) /$ $\left(1.3 / 0.7^{\circ} \mathrm{C}\right)$ accordingly. In the cases with direct solar load and supply airflow $180 \mathrm{l} / \mathrm{s}$, vertical temperature gradients were $\left(1.4 / 0.7^{\circ} \mathrm{C}\right) /\left(0.0 /-0.4^{\circ} \mathrm{C}\right)$ and $(2.3$ $\left./ 2.9^{\circ} \mathrm{C}\right) /\left(0.5 / 0.3{ }^{\circ} \mathrm{C}\right)$ accordingly. Diffuser installation on wall at $2.7 \mathrm{~m}$ height can clearly reduce vertical temperature gradient in occupied zone in all cases.

Vertical temperature gradients between $1.8 \mathrm{~m}$ height and highest measurement location near ceiling in the cases without direct solar load were $\left(1.3 / 1.1^{\circ} \mathrm{C}\right) /(1.3 /$ $\left.1.1^{\circ} \mathrm{C}\right)$ [diffuser floor installation $(5.1 \mathrm{~m} / 3.3 \mathrm{~m}$ room $) /$ wall installation at $2.7 \mathrm{~m}(5.1 \mathrm{~m} / 3.3 \mathrm{~m}$ room $)]$. In the cases with direct solar load and supply airflow $100 \mathrm{l} / \mathrm{s}$, vertical temperature gradients were $\left(1.2 / 1.0^{\circ} \mathrm{C}\right) /(1.2 /$ $0.9^{\circ} \mathrm{C}$ ) accordingly. In the cases with direct solar load and supply airflow $180 \mathrm{l} / \mathrm{s}$, vertical temperature gradients were $\left(1.2 / 1.1^{\circ} \mathrm{C}\right) /\left(1.2 / 0.8^{\circ} \mathrm{C}\right)$ accordingly. Diffuser installation on wall at $2.7 \mathrm{~m}$ height can maintain same room air vertical temperature gradient above occupied zone in all cases when compared to the case with diffuser floor installation.

\section{Discussion}

New knowledge of reduction of vertical temperature gradient in the occupied zone and ability to still maintain similar temperature gradient above the occupied zone with diffuser installation at $2.7 \mathrm{~m}$ from floor, when compared to floor installation, was found. This allows the use of cooler supply air temperatures without causing too big vertical temperature gradient to occupied zone, and thus smaller supply airflow rate for providing required cooling capacity. This could also reduce the ventilation system duct sizes and help the usage of displacement ventilation in the cases with high heat loads.

These results can be used for cases with $2.7 \mathrm{~m}$ or lower diffuser installation height and air supply downward along wall surface. If diffusers would be installed to higher location, the vertical temperature gradient above the occupied zone might not be preserved similar as in floor installation cases. It is notable that quite similar temperature gradient can be measured both in $3.3 \mathrm{~m}$ high and in $5.1 \mathrm{~m}$ high simulated office rooms. Installation of displacement diffusers above occupied zone without wall surface should be studied separately. In that situation induction of room air would be stronger than with wall jet effecting to the vertical temperature gradient.

When vertical temperature gradient and exhaust air temperatures of the wall installation cases at $2.7 \mathrm{~m}$ height were shifted with supply air temperature difference between wall and floor installation cases with same heat load setting, there were from $-1.0^{\circ} \mathrm{C}$ to $0.4{ }^{\circ} \mathrm{C}$ differences in the exhaust air temperatures. This meant differences from $-120 \mathrm{~W}$ to $86 \mathrm{~W}$ in effective room heat load level. Reasons for that were most probably differences in test conditions and thus heat transfer through test room walls, and measurement accuracy. These differences should be studied later with CFD simulation by using model with heat transfer in solid test room walls and ambient temperatures. The differences are still so small that the presented test results and comparisons are valid.

Local thermal comfort characteristics near the displacement diffusers differ from the case with more traditional floor installation to the case with wall installation above occupied zone. Air velocities were not measured in these cases near the diffusers or in the occupied zone. Still air distribution was visualized with smoke to study the throw pattern. According to that there was moderate air movement in all cases and no room air circulation with high velocity were noticed disturbing 
the convection flows from heat sources. One factor effecting to that was diffuser sizing with low face velocity from perforated front plate of displacement diffusers $0.08 / 0.14 \mathrm{~m} / \mathrm{s}(100 / 180$ l/s case $)$. According smoke visualization supply air jet in the case with wall installation was attached to the wall surface and came to floor as thinner flow than in the floor installation where it is it is distributed sidewise and arrives to floor level a bit farer in occupied zone. Still in wall installation, the velocity of supply air jet might increase more due to gravitation effecting to cool airflow supplied downwards. The cases with higher face velocity and higher than $2.7 \mathrm{~m}$ installation of displacement diffusers should be studied further.

Indoor air quality in the occupied zone of the simulated office rooms was not measured with tracer gas. This would be useful, for comparing the effect of wall installation above occupied zone to floor installation. Typically, indoor air quality in the occupied zone is better with displacement ventilation, with supply air diffusers installed in the occupied zone, than with mixing ventilation. With wall installation, it might be a bit closer to mixing ventilation. Still when taking into account that similar vertical temperature gradient can be maintained above the occupied zone in both installation situations, difference in the indoor air quality in the studied cases might not be very significant.

The effect of using lower or higher supply airflow rate can be seen clearly in the vertical temperature gradients with displacement diffuser installation on floor. With smaller supply airflow rate and higher heat load level (cases with direct solar load), vertical temperature gradient in the occupied zone is clearly bigger. With wall installation above the occupied zone, there are smaller changes in the vertical temperature gradient of the occupied zone.

\section{Conclusions}

The Simulated office room cases with installation of displacement diffuser above occupied zone and near wall at $2.7 \mathrm{~m}$ height, and on floor was studied in full-scale test cases. Following can be concluded of the installation of displacement ventilation diffusers above occupied zone:

- The vertical temperature gradient in simulated office rooms above the occupied zone was influenced only slightly with this installation and was very similar as with displacement diffuser installation on floor.

- The vertical temperature gradient in the occupied zone was reduced, which gives possibilities to use cooler supply air temperatures.

- This study confirmed the operation of the displacement ventilation with this kind of installations. It was recommended to study further local room air velocities near the diffusers for ensuring local thermal comfort in the room.

\section{References}

1. R. Kosonen, P. Mustakallio, Proceedings of Clima 2010, 10th. REHVA World Congress, Sustainable Energy Use in Buildings (2010)

2. R. Kosonen, A. Melikov, E. Mundt, P. Mustakallio, P.V. Nielsen, Displacement Ventilation, REHVA Guidebook No 23 (2017)

3. R. Kosonen, N. Lastovets, P. Mustakallio, G. C. da Graca, N. M. Mateus, M. Rosenqvist, Building and Environment, 108, 207-219 (2015)

4. N. Lastovets, R. Kosonen, P. Mustakallio, J. Jokisalo, A. Li, International Journal of Ventilation, Published online (2019)

5. P. Mustakallio, M. Rosenqvist, Y. Sinai, R. Kosonen, Proceedings of the 10th International Conference on Ventilation (2012) 